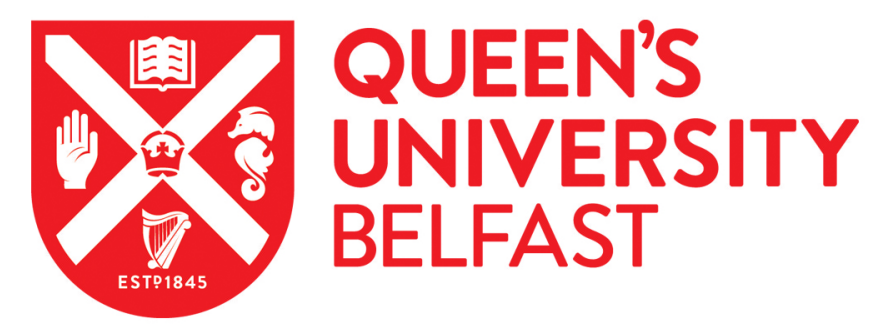

\title{
Rapid defaunation of terrestrial mammals in a protected Neotropical cloud forest remnant
}

Hoskins, H. M. J., McCann, N. P., Jocque, M., \& Reid, N. (2020). Rapid defaunation of terrestrial mammals in a protected Neotropical cloud forest remnant. Journal for Nature Conservation, 56, [125861].

https://doi.org/10.1016/j.jnc.2020.125861

\section{Published in:}

Journal for Nature Conservation

\section{Document Version:}

Peer reviewed version

\section{Queen's University Belfast - Research Portal:}

Link to publication record in Queen's University Belfast Research Portal

\section{Publisher rights}

(C) 2020 Elsevier GmbH

This manuscript is distributed under a Creative Commons Attribution-NonCommercial-NoDerivs License

(https://creativecommons.org/licenses/by-nc-nd/4.0/), which permits distribution and reproduction for non-commercial purposes, provided the author and source are cited.

\section{General rights}

Copyright for the publications made accessible via the Queen's University Belfast Research Portal is retained by the author(s) and / or other copyright owners and it is a condition of accessing these publications that users recognise and abide by the legal requirements associated with these rights.

Take down policy

The Research Portal is Queen's institutional repository that provides access to Queen's research output. Every effort has been made to ensure that content in the Research Portal does not infringe any person's rights, or applicable UK laws. If you discover content in the Research Portal that you believe breaches copyright or violates any law, please contact openaccess@qub.ac.uk. 


\section{递2 QUEEN'S \\ 9. UNIVERSITY BELFAST

\section{Rapid defaunation of terrestrial mammals in a protected Neotropical cloud forest remnant}

Hoskins, H., Jocque, M., McCann, N., \& Reid, N. (Accepted/In press). Rapid defaunation of terrestrial mammals in a protected Neotropical cloud forest remnant. Journal of Nature Conservation.

\section{Published in:}

Journal of Nature Conservation

\section{Document Version:}

Peer reviewed version

Queen's University Belfast - Research Portal:

Link to publication record in Queen's University Belfast Research Portal

\section{Publisher rights}

Copyright (C) 2020 Elsevier $\mathrm{GmbH}$.

This manuscript is distributed under a Creative Commons Attribution-NonCommercial-NoDerivs License

(https://creativecommons.org/licenses/by-nc-nd/4.0/), which permits distribution and reproduction for non-commercial purposes, provided the author and source are cited.

\section{General rights}

Copyright for the publications made accessible via the Queen's University Belfast Research Portal is retained by the author(s) and / or other copyright owners and it is a condition of accessing these publications that users recognise and abide by the legal requirements associated with these rights.

Take down policy

The Research Portal is Queen's institutional repository that provides access to Queen's research output. Every effort has been made to ensure that content in the Research Portal does not infringe any person's rights, or applicable UK laws. If you discover content in the Research Portal that you believe breaches copyright or violates any law, please contact openaccess@qub.ac.uk. 


\section{Title}

Rapid defaunation of terrestrial mammals in a protected Neotropical cloud forest remnant

\section{Author names and affiliations}

Hannah M. J. Hoskins ${ }^{1,2 *}$ hhoskins01@qub.ac.uk, 00447845674900

Niall P. McCann² niallmccann@hotmail.com

Merlijn Jocque ${ }^{2,3}$ merlijnjocque@gmail

Neil Reid ${ }^{1,4}$ neil.reid@qub.ac.uk

${ }^{1}$ School of Biological Sciences, Queen's University Belfast, 19 Chlorine Gardens, Belfast, BT9 5DL

${ }^{2}$ Operation Wallacea, Wallace House, Old Bolingbroke, Lincolnshire, PE23 4EX, UK

${ }^{3}$ Royal Belgian Institute of Natural Sciences, Aquatic \& Terrestrial Ecology, Vautierstraat 29, 1000 Brussels, Belgium.

${ }^{4}$ Institute of Global Food Security (IGFS), Queen's University Belfast, 19 Chlorine Gardens, Belfast, BT9 5DL

* corresponding author

\section{Highlights}

- Rapid defaunation of a Neotropical forest

- Zonal protection offered little protection buffering mammal population declines

- Governments and NGOs must act to avert the complete defaunation of terrestrial mammals in Cusuco National Park, Honduras 


\section{Abstract}

Macroecological analyses capture the widespread nature of wild mammal range contractions and population declines globally, with Neotropical rainforests particularly vulnerable. Yet there is a paucity of basic population biology data capturing local empirically observed population changes. We generated species-specific and aggregated temporal trends in populations of terrestrial mammals in Cusuco National Park, north-west Honduras testing the effects of body-size, hunting and zonal protection measures. Hunted species, regardless of body size, exhibited declines (ca. $-7 \%$ per year) with greater rapidity of decline in the park's more accessible and less rigorously protected buffer zone. The site was once regarded as a remaining strong of Baird's tapir (Tapirus bairdii), IUCN Red Listed as Endangered, but our data suggest its near local extirpation from monitored sites. Hunted deer (Mazama temama and Odocoileus virginianus) and paca (Cuniculus paca) also declined substantially. Whilst specific-species trends varied among unhunted species (e.g. wild cats, mustelids etc.) they, nevertheless, also exhibited an aggregated decline throughout the park ( $c a .-6 \%$ per year). Such was the rapidity of these declines that we estimate complete mammalian defaunation of Cusuco National Park by the mid-2020s leaving a notionally highly protected area mostly devoid of terrestrial mammals and the associated ecosystem services they deliver (so-called 'empty forest syndrome'). We call on Governments and non-governmental organizations including conservation charities to prioritize urgent efforts to secure funding and personnel to ensure designated areas are adequately protected with enforcement of existing legislative protection whether through patrols or capacity building to efficiently curtail ongoing defaunation.

Keywords: bushmeat, designated site, General Additive Mixed Models, illegal poaching, population decline, protected area, temporal trends 


\section{Funding}

This work was funded by the Department for Employment and Learning (DEL), Northern Ireland (www.delni.gov.uk) and supported by Operation Wallacea Ltd (www.opwall.com). Permits to carry out research were obtained from the Instituto Nacional de Conservación y Desarrollo Forestal Áreas Protegidas y Vida Silvestre (ICF), or National Institute for Conservation and Forestry Development, Protected Areas and Wildlife. 


\section{Introduction}

Defaunation can be defined as decrease in individual animal species abundance with associated range contraction often affecting whole communities or taxonomic groups resulting in their disappearance from a defined geographical area or habitat with associated ecosystem function loss (Dirzo et al., 2014). Terrestrial mammals, notably large-bodied species, are at comparatively high risk of landscape-level defaunation (Young, McCauley, Galetti, \& Dirzo, 2016). Geographically, tropical biodiversity hotspots (Dirzo et al., 2014), especially isolated habitats, from islands to mountaintops, are also at comparatively high risk (Young, McCauley, Galetti, \& Dirzo, 2016).

There are a multitude of processes driving population declines. Overexploitation as a driver of population declines includes a number of threats such as unsustainable hunting yields, notably for $k$-selected species (i.e. those with large body sizes, low fecundity and long maturation times; Galetti et al., 2017). Meta-analysis of hunting motivation suggests commercial rather than subsistence hunting is most damaging to wild mammal populations (Young et al., 2016) and where hunting is the main threat, selective forces result in so-called 'anthropogenic downsizing' reducing mean mammal body size (Young et al., 2016). More than $75 \%$ of forests have been anthropogenically altered (Potapov et al., 2008) with habitat loss, both through total destruction and degradation, being a major cause of landscape defaunation (Young et al., 2016); although such processes may be slow with population declines going unnoticed and unrecorded (Gaston, 2010). Human-induced disease spread (e.g. ecotourists infecting great apes with zoonotic pathogens; Muehlenbein \& Ancrenaz, 2009), pollution (most infamously DDT leading to dramatic declines in bird populations; Carson, 1962), and climate change (through species range shifts; Chen, Hill, Ohlemuller, Roy, \& Thomas, 2011) additionally drive defaunation. 
Defaunation results in loss of ecosystem functioning through shifts in community composition (Culot, Bovy, Vaz-de-Mello, Guevara, \& Galetti, 2013), changes to predation (Galetti et al., 2013) and loss of prey (Sandom et al., 2017). Consequences may not be immediate, for example, trophic cascades resulting in mesopredator release may eventually critically alter ecosystem function (Ellingsen et al., 2015) or forested systems that are devoid of mammals and birds resulting in a reduced carbon storage capacity (Osuri et al., 2016).

Defaunation is a direct driver of the current global biodiversity crisis; wildlife population abundance declined on average by 60\% between 1970 and 2014 (WWF, 2018) with vertebrate extinction rates 100 times higher than natural background rates (Ceballos et al., 2015). Declines in faunal abundances within the Neotropics have been, on average, $89 \%$ over 34 years with ca. 5\% annual loss (WWF, 2018). In spite of the global number of protected area designations reaching an all-time high, defaunation persists (Coad et al., 2019; WWF, 2018; IPBES, 2019) with protected areas within the Neotropics the most ineffectively managed and resourced worldwide (Coad et al., 2019).

This study aimed to quantify relative abundances and analyze temporal trends in a terrestrial mammal community within a (notionally) highly protected Neotropical cloud forest remnant: Cusuco National Park, northwest Honduras. The specific objectives were to i) establish monitoring and surveillance of species-specific tracks and signs over overtime and ii) assess overall temporal trends and interannual fluctuations in each species as well as aggregated groups i.e. large hunted, small hunted and unhunted species. Our hypotheses were a) that mammals have declined over time despite the protected area being designated as a National Park, b) large-bodied hunted species exhibit stronger negative trends than smallbodied unhunted species, c) declines are stronger in the National Park's more disturbed buffer zone than the more protected core zone (testing the effects of zonal protection). Our analyses quantified local defaunation rates (average percentage change in relative abundance over nine 
years of monitoring) focusing on body-size and hunting as the most likely drivers of loss rates. Such knowledge is essential for Government departments, forestry agencies, legislative enforcement operatives and conservationists to raise the alarm allowing protection efforts to be re-enforced, preventing local species extirpations.

\section{Methods}

Survey site

Parque Nacional Cusuco (throughout referred to as Cusuco National Park) is 23,440 hectares of protected land in the Sierra de Omoa of the Merendón mountain range, Cortés, north-west Honduras $\left(15^{\circ} 32^{\prime} 31^{\prime \prime} \mathrm{N}, 088^{\circ} 15^{\prime} 49^{\prime \prime} \mathrm{W}\right)$. The Honduran Government designated it under the Water Protection Act 1987 to protect the water source of the nearby city of San Pedro Sula (with up to $1.5 \mathrm{M}$ people in the local metropolitan area, some of which may use the park recreationally). The park has two levels of zonal protection; a core zone of 7,690 hectares surrounded by a buffer zone of 15,750ha. This zonal delineation occurred during 1994, designed by the Corporación Hondureña de Desarrollo Forestal (COHDEFOR), implementing a park management plan where in the core zone agriculture, burning, mining, hunting, construction of roads, houses, or commercial, public and private institutions or any human settlements are not permitted (ICF, 1987). Within the buffer zone restricted activity of the above is permitted (although no new clearing or hunting is allowed, there are existing human settlements and associated activities). There is a lack of local enforcement of protection and no (or very few) prosecutions means that Cusuco National Park may represent little more than a "paper park" (Martin \& Blackburn, 2009). 
Monitoring and surveillance of terrestrial mammal tracks and signs (footprints, scat, food remains with species-specific bite marks, scratch marks and vocalizations) were recorded along line transects $(2-4 \mathrm{~km}$ long) radiating out from seven research stations or camps (Fig. 1) during June-August annually from 2010 to 2018. Transect trials were maintained annually by cutting with machetes with surveys occurring during early morning after the active period for nocturnal mammals. Surveyors (professional academic mammologists), their student(s) plus an experienced local animal tracking guide (for the most part the same person annually) walked transects at a speed of $1-2 \mathrm{~km} /$ hour recording species occurrences georeferenced using a handheld GPS unit. The maintenance of a standardized survey protocol was used to generate a consistent time-series dataset of species relative abundance expressed as the number of records $(n=2478)$ per species $(n=19)$ per transect $(n=27)$ per year $(n=9)$ yielding a total of 243 transect/years.

\section{Statistical analysis}

Geographic Information Systems (GIS) was used to map transect locations relative to the core and buffer zone boundary using ArcMap 10.5 (ESRI, California, USA). Descriptive statistics (numbers of species occurrence records) were tabulated each year. Individual species were pooled (aggregated) into three categories: large ( $>2 \mathrm{~kg})$ hunted species (see Table 1) using mean species body weight extracted from Reid (2009) whilst hunted or unhunted status was determined from local hunting questionnaires conducted within villages within the park (Hoskins, unpublished data).

Prior to analyses, occurrence records were standardized by survey effort by expressing relative abundance (number of detections) per species per transect using both the length of each transect in kilometers (transects varied in length) and the number of replicate surveys of 
each transect (some were surveyed more than once per year). Thus, standardized species counts were expressed in detections/km surveyed. Transects that crossed the core/buffer zone boundary were split into sub-transects so that differences in associated relative abundance between zones could be tested.

Two approaches were used to quantify change in mammal relative abundance over time. General Linear Models (GLMs) were used to assess the effect of Year fitted as a continuous variable such that its effect size i.e. standardized slope $(\beta \pm$ s.e.), and its significance ( $p$ value), were estimated. This approach allowed those species with consistent changes over time to be identified. Some species may exhibit substantial fluctuations in their population over time but may not exhibit an overall trend. Thus, to capture whether populations exhibited significant interannual fluctuation, General Additive Mixed Models (GAMMs) were used to assess the effect of Year fitted as a fixed factor such that annual estimates of relative abundance were modelled. Both GLMs and GAMMs assumed a quasi-Poisson distribution (for non-integer overdispersed count data). GAMMs were fitted using a Restricted Estimation Maximum Likelihood (REML) procedure. Research station (camp) was fitted as a Random Factor to account for pseudoreplication i.e. multiple transects per camp (a proxy for spatial location). A smoothing function for nonlinear trends adopted 4 'knots' or change points following the methods of Fewster, Buckland, Siriwardena, Baillie, \& Wilson (2000) using the greatest number of knots that permitted model convergence. Models were constructed for each species group (large hunted, small hunted and unhunted species aggregated) and for each species individually. In order to assess the impact of anthropogenic disturbance, separate models were fitted for the core and buffer zones. GLMs were fitted using the mass package (Venables \& Ripley, 2002) and GAMMs the mgcv package (Wood, 2011) for R (R Core Team, 2018). Species' overall mean change was expressed as the percentage difference between the modelled value for 2010 (first year) compared to 2018 
(last year). Graphical plots of GAMM fitted values \pm 95\% Confidence Intervals were created using ggplot2 (Wickham, 2016).

\section{Results}

A total of 2478 occurrence records of 19 terrestrial mammal species were collected from 2010 to 2018 with most records for large hunted species (51\%), for example, Baird's tapir and brocket deer (Table 1). Some species, for example, white-nosed coati, were notably common (in this case accounting for $20 \%$ of all records and $58 \%$ of unhunted species records). Not all species were detected each year of the time-series; notably rare species included jaguarundi (recorded during just two years) or the long-tailed weasel (recorded in one year only).

Aggregated tracks and signs suggested the entire mammal community declined by $c a$. 7\%/yr from 2010 to 2018 declining 70\% in the buffer and $62 \%$ in the core zone. Such was the severity of declines among each of the mammal groupings (large and small hunted and unhunted species) in both the core and buffer zones that it was estimated Cusuco National Park may be largely empty of mammals by the mid-2020s (Fig. 2).

GLM linear trends suggested significant declines in large and small hunted species in the park's buffer zone ( $85 \%$ and $86 \%$ respectively) and, though weaker, declines in the core zone were still significant (64\% and 56\% respectively; Table 2). In contrast, linear declines of unhunted species were significant and highest in the core zone (59\%) and non-significant and lowest in the buffer zone $(27 \%)$.

Baird's tapir was never recorded in the buffer zone and apparently experienced complete extirpation in the core zone (100\%) with significant inter-annual (GAMM) fluctuations 
(Table 2) suggesting an initially rapid decline from 2010 to 2012 before stabilization for 3-4 years before continued decline to zero tracks or signs being detected in 2018 (Table 2; Fig. 3). Brocket deer also exhibited significant inter-annual fluctuation with declines in both the core and buffer zones ( $85 \%$ and $77 \%$ respectively; Table 2$)$. Nine-banded armadillo exhibited contrasting trends between zones with significant inter-annual fluctuations resulting in a nonlinear increase in the core zone (96\%) yet complete extirpation in the buffer zone (Table 2; Fig. 3).

Of the small hunted species, lowland paca exhibited significant inter-annual fluctuations in both the core and buffer with a $45 \%$ linear decline in the core zone and an $87 \%$ linear decline in the buffer (Table 2). Agouti were only recorded in 2013 and 2014 with a large number of records during 2014 (Table 1; Fig. 3).

There were no consistent trends between individual unhunted species though taken together they declined significantly by $59 \%$ in the core and non-significantly by $27 \%$ in the buffer zone (Table 2). There were significant inter-annual fluctuations in detections of skunk and white-nosed coati in the buffer zone with the former increasing by $90 \%$ (not significant) and the latter by $395 \%$ (significant; Table 2). Ocelot, raccoon and gray fox significantly declined in the core zone with no detections of any by the end of the time-series.

\section{Discussion}

We show that within Cusuco National Park, Honduras, hunted species, regardless of body size, exhibited the greatest population declines from 2010 to 2018 ; mostly notably in the park's less protected buffer zone. Baird's tapir, IUCN Red Listed as Endangered throughout its Central American range (Garcìa, 2016), appears to be locally extirpated. Many unhunted species exhibited no significant linear trend, but taken as a group, they nonetheless also 
declined in both zones, most notably in the core zone. The total (aggregated) loss of mammals throughout Cusuco National Park (62-70\% over nine years) is comparable to that reported by Benitez-Lopez et al., (2017) for tropical terrestrial mammals where populations have declined by $72-90 \%$ in areas were hunting occurs compared to hunting-free areas over the same time scale. Such was the severity of declines we anticipate complete mammalian defaunation of studied species in the national park by the mid-2020s.

For most part, those species that exhibited significant inter-annual fluctuations also exhibited significant linear trends (mostly decreases with occasional fluctuations). Declines of hunted species were generally greater in the less protected buffer zone perhaps indicative of some degree of better (yet cumulatively inadequate) protection though this may also be an artefact of the comparative geographically isolation of the core zone (at higher elevation with steeper slopes) surrounded by the lower elevation and flatter terrain of the buffer zone (Gaveau et al., 2009).

Like hunted species, unhunted species declined in both the buffer and core zones, but contrasted with hunted species, declines were greatest in the core rather than the buffer zone. Some of these species were not recorded commonly and suffered low sample sizes in terms of detections; thus, interspecific contrasts in temporal patterns may reflect stochasticity in their detection (Fig. 3). However, it may also be that this community is more tolerant of anthropogenic disturbance, being more common in the buffer than core zone. Populations exposed to disturbance in the buffer zone may have already declined previously and thus be starting from a lower baseline resulting in weaker declines. Moreover, stronger declines of unhunted species in the core zone may suggest the presence of other sources of anthropogenic disturbance beyond hunting as a driver of population decline, for example, direct disturbance from deforestation. Due to low annual detection of mammalian species, it was not possible to 
conduct spatially explicit analysis of environmental drivers of declines beyond capturing overall population trends.

Baird's tapir, brocket deer and paca are preferred game and although hunting is illegal, discovery of hunting platforms, interviews with locals and discovery of hunting paraphernalia (including spent shell casings) indicate that hunting does occur and is widespread (Supplementary Materials Fig. S1). The apparent local extirpation of Baird's tapir is most concerning as Cusuco National Park was previously noted as one of the last remaining strongholds for the species (Gilroy et al., 2017; McCann, 2015, Hoskins et al., 2018), even though its local status was predicted as precarious with likely extinction imminent (McCann, Wheeler, Coles, \& Bruford, 2012). We suggests that the IUCN Range status for this population be updated from "extant (resident)" and reclassed as "possibly extant (resident)" indicative of the uncertainty that tapir remain in unsurveyed areas (Supplementary Materials Fig. S2).

Animal population abundances are not static but rather can be affected by inter-annual and multiannual fluctuations (Sexton, McIntyre, Angert, \& Rice, 2009; Vucetich, Waite, Qvarnemark, \& Ibarguen, 2000), even in the absence of direct anthropogenic influence. Such changes may arise from the effects of natural changes to resource availability (Yang, Bastow, Spence, \& Wright, 2008), climate (Bodmer et al., 2018), and density-dependent effects of predation (Owen-Smith, 2015), disease and/or parasitism (Thornhill \& Fincher, 2013). However, anthropogenically mediated declines overriding such (natural) variation have been demonstrated elsewhere (Toews, Juanes, \& Burton, 2018), in some cases enhancing the drivers of such variation (Chanchani, Gerber, \& Noon, 2018). The potential impacts of such anthropogenic effects is variable but may lead to extinction of local populations (WWF, 2018), entire species (Ripple et al., 2019; Ceballos et al., 2015) and alteration of community structure (Hagen et al., 2012). 
Loss of diversity has wide-reaching consequences on ecosystem function enhancing other threats to biodiversity (Cooke, Eigenbrod, \& Bates, 2019; Jorge, Galetti, Ribeiro, \& Ferraz, 2013; Soliveres et al., 2016; Villar et al., 2020). Loss of herbivores and frugivores (e.g. tapir, deer, peccaries etc.), due to loss of their role in herbivory and seed dispersal (Nunez-Iturri, Olsson, \& Howe, 2008; Wotton \& Kelly, 2011), may weaken biological resilience (forest maintenance) driving further habitat degradation and defaunation.

The majority of defaunation studies are at macroecological scales (e.g. Keith et al., 2015), and although this is useful in quantifying broad (global) patterns, they often lack inclusion of robust empirical observations of population loss at the local level (Rios-Saldana, DelibesMateos, \& Ferreira, 2018). Collection of first-hand observation data on changes in species detection rates within specific systems (i.e. basic population biology) is necessary (RiosSaldana et al., 2018).

\section{Conclusion}

This study provides empirical observation data on the rapid defaunation of terrestrial mammal communities within notionally highly protected areas, for example, National Parks, within the Neotropics. We demonstrate an urgent need to enforce legislative protections aimed at the cessation of illegal hunting activities before exploring future management options long-term (Palacios, Naveda-Rodriguez, \& Zapata-Rios, 2018). If total extirpation occurs before protective management programs are enacted, there will be none of these mammals left to protect. The Instituto Nacional de Conservación y Desarrollo Forestal (ICF) is the Honduran forestry department responsible for ensuring Cusuco National Park is protected. Moreover, the non-government organisation (NGO) Panthera (www.panthera.org) has highlighted the importance of Cusuco National Park in providing a movement corridor 
for large carnivores, for example, jaguar (Panthera onca) dependent on forests stocked with suitable prey (Petracca et al., 2014). Operation Wallacea Ltd. supports local monitoring and surveillance of numerous taxa and is responsible for significant financial investment each year in Honduras (Tim Coles pers. comm.) which may be much reduced should ecosystem integrity collapse i.e. trashed habitats don't attract ecotourists (Galetti et al., 2017). The monetary value of the standing forests in carbon sequestration and their associated market value is also threatened as forests devoid of mammals have diminished carbon stocks (Krause $\&$ Nielsen, 2019). This indicates that conservation efforts already in place must be intensified. There are preliminary data that suggest hunters avoid areas patrolled by park guards (Franklin Castañeda, unpublished data) and yet such patrols in Cusuco National Park are highly geographically restricted and occur only during certain days of the month. Thus, the urgency of ensuring patrols to prevent both deforestation and illegal hunting cannot be overstated to provide evidence supporting prosecutions for illegal activity whilst increasing awareness of such enforcement within local communities may act as a preventative measure. We call on the Honduran government including ICF, and supporting organizations to focus all efforts on securing funds and personnel to ensure Cusuco National Park is adequately protected to allow mammal populations to recover and ensure associated ecosystem service delivery.

\section{Acknowledgments}

Authors are grateful to all those who have contributed to data collection; Mito Alvarenga, Roger Alvarenga, Ryan Gardiner, Martha Nash, Eric McNeil, Miguel Mejia, Louise Outlaw, Sam Puls, Eliott Spiller, Katie Spencer, Nina Storm. Furthermore we would like to thank Tom Martin, Thomas Creedy and Sam Jones for their advice. We acknowledge the Instituto 
de Conservación Forestal (ICF), who maintain the Base camp facilities. We are particularly grateful to Roberto Downing, Declan Crace, and Tim Coles, without whom fieldwork would not have been logistically possible. 


\section{References}

Benitez-Lopez, A., Alkemade, R., Schipper, A. M., Ingram, D. J., Verweij, P. A., Eikelboom, J. A. J., \& Huijbregts, M. A. J. (2017). The impact of hunting on tropical mammal and bird populations. Science, 356(6334), 180-183. doi:10.1126/science.aaj1891

Bodmer, R., Mayor, P., Antunez, M., Chota, K., Fang, T., Puertas, P., . . . Docherty, E. (2018). Major shifts in Amazon wildlife populations from recent intensification of floods and drought. Conservation Biology, 32(2), 333-344. doi:10.1111/cobi.12993

Carson, R. (1962). Silent Spring. Cambridge, Massachusetts: Houghton Mifflin.

Ceballos, G., Ehrlich, P. R., Barnosky, A. D., Garcia, A., Pringle, R. M., \& Palmer, T. M. (2015). Accelerated modern human-induced species losses: Entering the sixth mass extinction. Science Advances, 1(5). doi:10.1126/sciadv.1400253

Chen, I. C., Hill, J. K., Ohlemuller, R., Roy, D. B., \& Thomas, C. D. (2011). Rapid Range Shifts of Species Associated with High Levels of Climate Warming. Science, 333(6045), 1024-1026. doi:10.1126/science.1206432

Coad, L., Watson, J. E. M., Geldmann, J., Burgess, N. D., Leverington, F., Hockings, M., . . . Di Marco, M. (2019). Widespread shortfalls in protected area resourcing undermine efforts to conserve biodiversity. Frontiers in Ecology and the Environment, 17(5), 259-264. doi:10.1002/fee.2042

Cooke, R. S. C., Eigenbrod, F., \& Bates, A. E. (2019). Projected losses of global mammal and bird ecological strategies. Nature Communications, 10. doi:10.1038/s41467-019$10284-\mathrm{Z}$

Chanchani, P., Gerber, B. D., \& Noon, B. R. (2018). Elevated potential for intraspecific competition in territorial carnivores occupying fragmented landscapes. Biological Conservation, 227, 275-283. doi:10.1016/j.biocon.2018.08.017 
Culot, L., Bovy, E., Vaz-de-Mello, F. Z., Guevara, R., \& Galetti, M. (2013). Selective defaunation affects dung beetle communities in continuous Atlantic rainforest. Biological Conservation, 163, 79-89. doi:10.1016/j.biocon.2013.04.004

Dirzo, R., Young, H. S., Galetti, M., Ceballos, G., Isaac, N. J. B., \& Collen, B. (2014). Defaunation in the Anthropocene. Science, 345(6195), 401-406. doi:10.1126/science. 1251817

Ellingsen, K. E., Anderson, M. J., Shackell, N. L., Tveraa, T., Yoccoz, N. G., \& Frank, K. T. (2015). The role of a dominant predator in shaping biodiversity over space and time in a marine ecosystem. Journal of Animal Ecology, 84(5), 1242-1252. doi:10.1111/13652656.12396

Fewster, R. M., Buckland, S. T., Siriwardena, G. M., Baillie, S. R., \& Wilson, J. D. (2000). Analysis of population trends for farmland birds using generalized additive models. Ecology, 81(7), 1970-1984. doi:10.1890/0012-9658(2000)081[1970:aoptff]2.0.co;2

Galetti, M., Brocardo, C. R., Begotti, R. A., Hortenci, L., Rocha-Mendes, F., Bernardo, C. S. S., ... Siqueira, T. (2017). Defaunation and biomass collapse of mammals in the largest Atlantic forest remnant. Animal Conservation, 20(3), 270-281. doi:10.1111/acv.12311

Galetti, M., Guevara, R., Cortes, M. C., Fadini, R., Von Matter, S., Leite, A. B., . . Jordano, P. (2013). Functional Extinction of Birds Drives Rapid Evolutionary Changes in Seed Size. Science, 340(6136), 1086-1090. doi:10.1126/science.1233774

Garcìa, M., Jordan, C., O'Farril, G., Poot, C., Meyer, N., Estrada, N., Leonardo, R., Naranjo, E., Simons, Á., Herrera, A., Urgilés, C., Schank, C., Boshoff, L. \& Ruiz-Galeano, M. (2016). Tapirus bairdii. The IUCN Red List of Threatened Species 2016:

e.T21471A45173340. http://dx.doi.org/10.2305/IUCN.UK.2016-

1.RLTS.T21471A45173340.en/ Accessed 03 August 2019. 
Gaston, K. J. (2010). Valuing Common Species. Science, 327(5962), 154-155. doi:10.1126/science. 1182818

Gaveau, D. L. A., Epting, J., Lyne, O., Linkie, M., Kumara, I., Kanninen, M., \& LeaderWilliams, N. (2009). Evaluating whether protected areas reduce tropical deforestation in Sumatra. Journal of Biogeography, 36(11), 2165-2175. doi:10.1111/j.13652699.2009.02147.x

Gilroy, D., Jones, S.E.I., Vulinec, K., Thompson, P., Hoskins, H.M.J., Creedy, T.J., Jocque, M., Green, S., Lonsdale, G., Phipps, C., Burdekin, O.J., Brown, T. (2017). Operation Wallacea Cusuco National Park, Honduras 2016 \& 2017: End of Season Report. Lincolnshire, U.K: Operation Wallacea Ltd.

Hagen, M., Kissling, W. D., Rasmussen, C., De Aguiar, M. A. M., Brown, L. E., Carstensen, D. W., ... Olesen, J. M. (2012). Biodiversity, Species Interactions and Ecological Networks in a Fragmented World. Advances in Ecological Research, Vol 46: Global Change in Multispecies Systems, Pt 1, 46, 89-210. doi:10.1016/b978-0-12-396992$7.00002-2$

Hoskins, H.M.J., Burdekin, O.J., Dicks, K., Slater, K.Y., McCann, N.P., Jocque, M., Castañeda, F., Reid, N. (2018). Non-volant mammal inventory of Cusuco National Park, north-west Honduras: reporting the presence of Jaguar, Panthera onca (Linnaeus, 1758), and demonstrating the effects of zonal protection on mammalian abundance. Check List 14(5): 877-891. doi: 10.15560/14.5.877

ICF. (1987). Decreto numero 87-87. http://icf.gob.hn/wp-content/ uploads/2015/09/APDecreto-87-87-Declaratoria-Bosques-Nublados.pdf/ Accessed 12 April 2019. IPBES. (2019). Summary for policymakers of the global assessment report on biodiversity and ecosystem services of the Intergovernmental Science-Policy Platform on Biodiversity and Ecosystem Services. Díaz, S., Settele, J., Brondizio, E.S., Ngo, H.T., 
Gueze, M., Agard, J., Arneth, A., Balvanera, P., Brauman, K.A., Butchart, S.H.M., Chan, K.M.A., Garibaldi, L.A., Ichii, K., Liu, J., Subramanian, S.M., Midgley, G.F., Miloslavich, P., Molnár, Z., Obura, D., Pfaff, A., Polasky, S., Purvis, A., Razzaque, J., Reyers, B., Roy Chowdhury, R., Shin, Y.J., Visseren-Hamakers, I.J., Willis, K.J., Zayas, C.N. (Eds.). Bonn, Germany: IPBES secretariat.

Jorge, M., Galetti, M., Ribeiro, M. C., \& Ferraz, K. (2013). Mammal defaunation as surrogate of trophic cascades in hotspot. Biological Conservation, 163, 49-57. doi:10.1016/j.biocon.2013.04.018

Keith, D., Akcakaya, H. R., Butchart, S. H. M., Collen, B., Dulvy, N. K., Holmes, E. E., .. . Waples, R. S. (2015). Temporal correlations in population trends: Conservation implications from time-series analysis of diverse animal taxa. Biological Conservation, 192, 247-257. doi:10.1016/j.biocon.2015.09.021

Krause, T., \& Nielsen, M. R. (2019). Not Seeing the Forest for the Trees: The Oversight of Defaunation in REDD plus and Global Forest Governance. Forests, 10(4). doi:10.3390/f10040344

Martin, T. E., \& Blackburn, G. A. (2009). The effectiveness of a Mesoamerican 'paper park' in conserving cloud forest avifauna. Biodiversity and Conservation, 18(14), 38413859. doi:10.1007/s10531-009-9683-6

McCann, N. P., Wheeler, P. M., Coles, T., \& Bruford, M. W. (2012). Rapid ongoing decline of Baird's tapir in Cusuco National Park, Honduras. Integrative Zoology, 7(4), 420428. doi:10.1111/j.1749-4877.2012.00312.x

McCann, N.P. (2015). The conservation of Baird's tapir (Tapirus bairdii) in Honduras. PhD thesis, Cardiff University, Cardiff, UK. 
Muehlenbein, M. P., \& Ancrenaz, M. (2009). Minimizing Pathogen Transmission at Primate Ecotourism Destinations: The Need for Input from Travel Medicine. Journal of Travel Medicine, 16(4), 229-232. doi:10.1111/j.1708-8305.2009.00346.x

Nunez-Iturri, G., Olsson, O., \& Howe, H. F. (2008). Hunting reduces recruitment of primatedispersed trees in Amazonian Peru. Biological Conservation, 141(6), 1536-1546. doi:10.1016/j.biocon.2008.03.020

Osuri, A. M., Ratnam, J., Varma, V., Alvarez-Loayza, P., Astaiza, J. H., Bradford, M., . . Sankaran, M. (2016). Contrasting effects of defaunation on aboveground carbon storage across the global tropics. Nature Communications, 7. doi:10.1038/ncomms 11351

Owen-Smith, N. (2015). Mechanisms of coexistence in diverse herbivore-carnivore assemblages: demographic, temporal and spatial heterogeneities affecting prey vulnerability. Oikos, 124(11), 1417-1426. doi:10.1111/oik.02218

Palacios, J., Naveda-Rodriguez, A., \& Zapata-Rios, G. (2018). Large mammal richness in Llanganates National Park, Ecuador. Mammalia, 82(4), 309-314. doi:10.1515/mammalia-2017-0071

Petracca, L. S., Hernandez-Potosme, S., Obando-Sampson, L., Salom-Perez, R., Quigley, H., \& Robinson, H. S. (2014). Agricultural encroachment and lack of enforcement threaten connectivity of range-wide jaguar (Panthera onca) corridor. Journal for Nature Conservation, 22(5), 436-444. doi:10.1016/j.jnc.2014.04.002

Potapov, P., Yaroshenko, A., Turubanova, S., Dubinin, M., Laestadius, L., Thies, C., . . . Zhuravleva, I. (2008). Mapping the World's Intact Forest Landscapes by Remote Sensing. Ecology and Society, 13(2).

R Core Team. (2018). R: A language and environment for statistical computing. Vienna, Austria: R Foundation for Statistical Computing. 
Reid, F. (2009) A Field Guide to the Mammals of Central America and Southeast Mexico, $2^{\text {nd }}$ Edition. New York: Oxford University Press.

Rios-Saldana, C. A., Delibes-Mateos, M., \& Ferreira, C. C. (2018). Are fieldwork studies being relegated to second place in conservation science? Global Ecology and Conservation, 14. doi:10.1016/j.gecco.2018.e00389

Ripple, W. J., Wolf, C., Newsome, T. M., Betts, M. G., Ceballos, G., Courchamp, F., . . . Worm, B. (2019). Are we eating the world's megafauna to extinction? Conservation Letters, 12(3). doi:10.1111/conl.12627

Sandom, C. J., Williams, J., Burnham, D., Dickman, A. J., Hinks, A. E., Macdonald, E. A., \& Macdonald, D. W. (2017). Deconstructed cat communities: Quantifying the threat to felids from prey defaunation. Diversity and Distributions, 23(6), 667-679. doi:10.1111/ddi.12558

Sexton, J. P., McIntyre, P. J., Angert, A. L., \& Rice, K. J. (2009). Evolution and Ecology of Species Range Limits. Annual Review of Ecology Evolution and Systematics, 40, 415 436. doi:10.1146/annurev.ecolsys. 110308.120317

Soliveres, S., van der Plas, F., Manning, P., Prati, D., Gossner, M. M., Renner, S. C., . . Allan, E. (2016). Biodiversity at multiple trophic levels is needed for ecosystem multifunctionality. Nature, 536(7617), 456-+. doi:10.1038/nature19092

Thornhill, R., \& Fincher, C. L. (2013). The parasite-driven-wedge model of parapatric speciation. Journal of Zoology, 291(1), 23-33. doi:10.1111/jzo.12070

Toews, M., Juanes, F., \& Burton, A. C. (2018). Mammal responses to the human footprint vary across species and stressors. Journal of Environmental Management, 217, 690699. doi:10.1016/j.jenvman.2018.04.009 
Venables, W. N., \& Ripley, B. D. (2002). Modern Applied Statistics with S. Fourth Edition. Springer, New York.

Villar, N., Siqueira, T., Zipparro, V., Farah, F., Schmaedecke, G., Hortenci, L., .. . Galetti, M. (2020). The cryptic regulation of diversity by functionally complementary large tropical forest herbivores. Journal of Ecology. doi:10.1111/1365-2745.13257

Vucetich, J. A., Waite, T. A., Qvarnemark, L., \& Ibarguen, S. (2000). Population variability and extinction risk. Conservation Biology, 14(6), 1704-1714. doi:10.1111/j.15231739.2000.99359.x

Wickham, H. (2016). ggplot2: Elegant Graphics for Data Analysis. New York: SpringerVerlag.

Wood, S.N. (2011). Fast stable restricted maximum likelihood and marginal likelihood estimation of semiparametric generalized linear models. Journal of the Royal Statistical Society (B), 73, 3-36.

Wotton, D. M., \& Kelly, D. (2011). Frugivore loss limits recruitment of large-seeded trees. Proceedings of the Royal Society B-Biological Sciences, 278(1723), 3345-3354. doi:10.1098/rspb.2011.0185

WWF. (2018). Living Planet Report - 2018: Aiming Higher. Grooten, M., Almond, R.E.A. (Eds.), Gland, Switzerland: WWF.

Yang, L. H., Bastow, J. L., Spence, K. O., \& Wright, A. N. (2008). What can we learn from resource pulses? Ecology, 89(3), 621-634. doi:10.1890/07-0175.1

Young, H. S., McCauley, D. J., Galetti, M., \& Dirzo, R. (2016). Patterns, Causes, and Consequences of Anthropocene Defaunation. Annual Review of Ecology, Evolution, and Systematics, Vol 47, 47, 333-358. doi:10.1146/annurev-ecolsys-112414-054142 


\section{Figures}

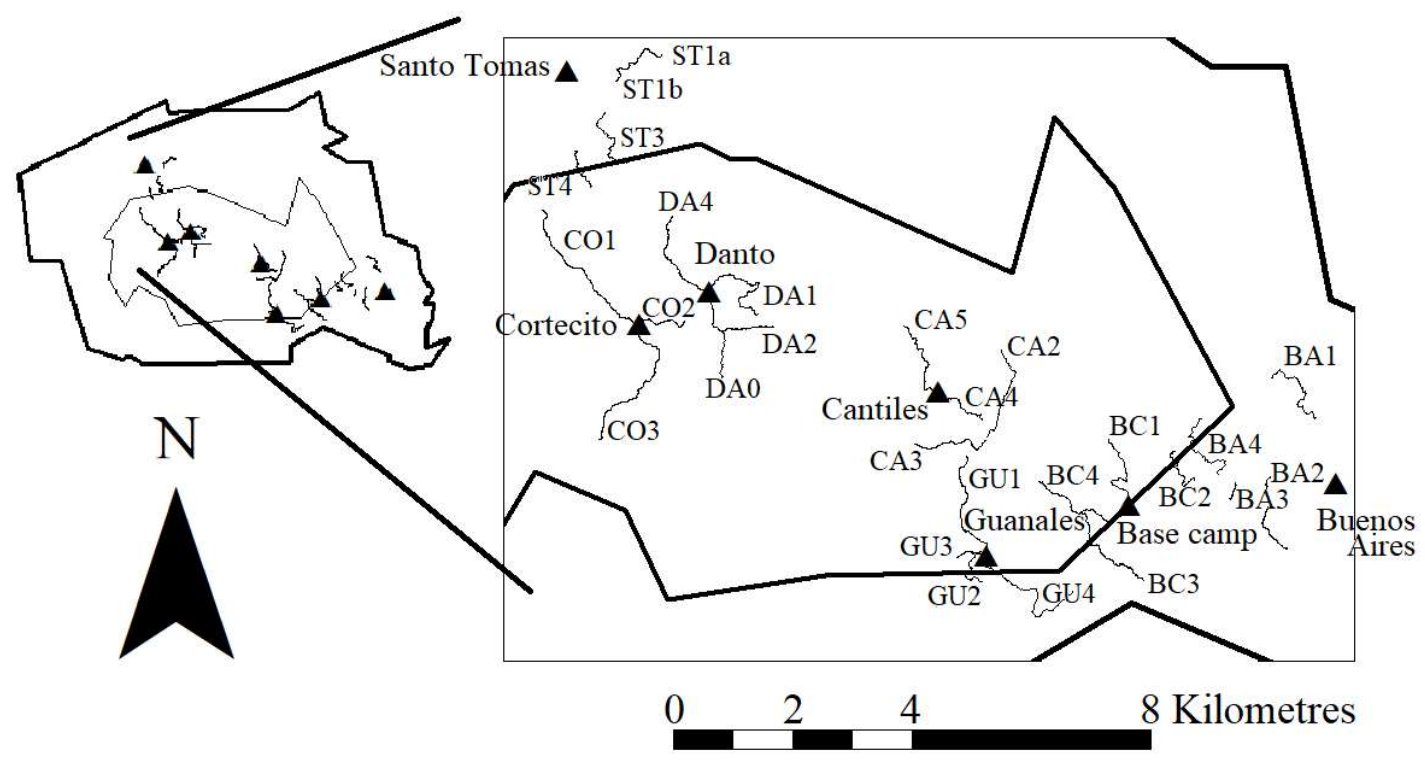

Fig. 1 Distribution of survey line transects (1-5) throughout Cusuco National Park, Honduras associated with each research station (aka camp): $\mathrm{BC}=$ Basecamp, $\mathrm{BA}=$ Buenos Aires, $\mathrm{GU}=$ Guanales, $\mathrm{CA}=$ Cantiles, $\mathrm{CO}=$ Cortecito, $\mathrm{DA}=$ Danto, $\mathrm{ST}=$ Santo Tomas. Outer polygon is the National Park buffer zone and inner polygon is the core zone. 

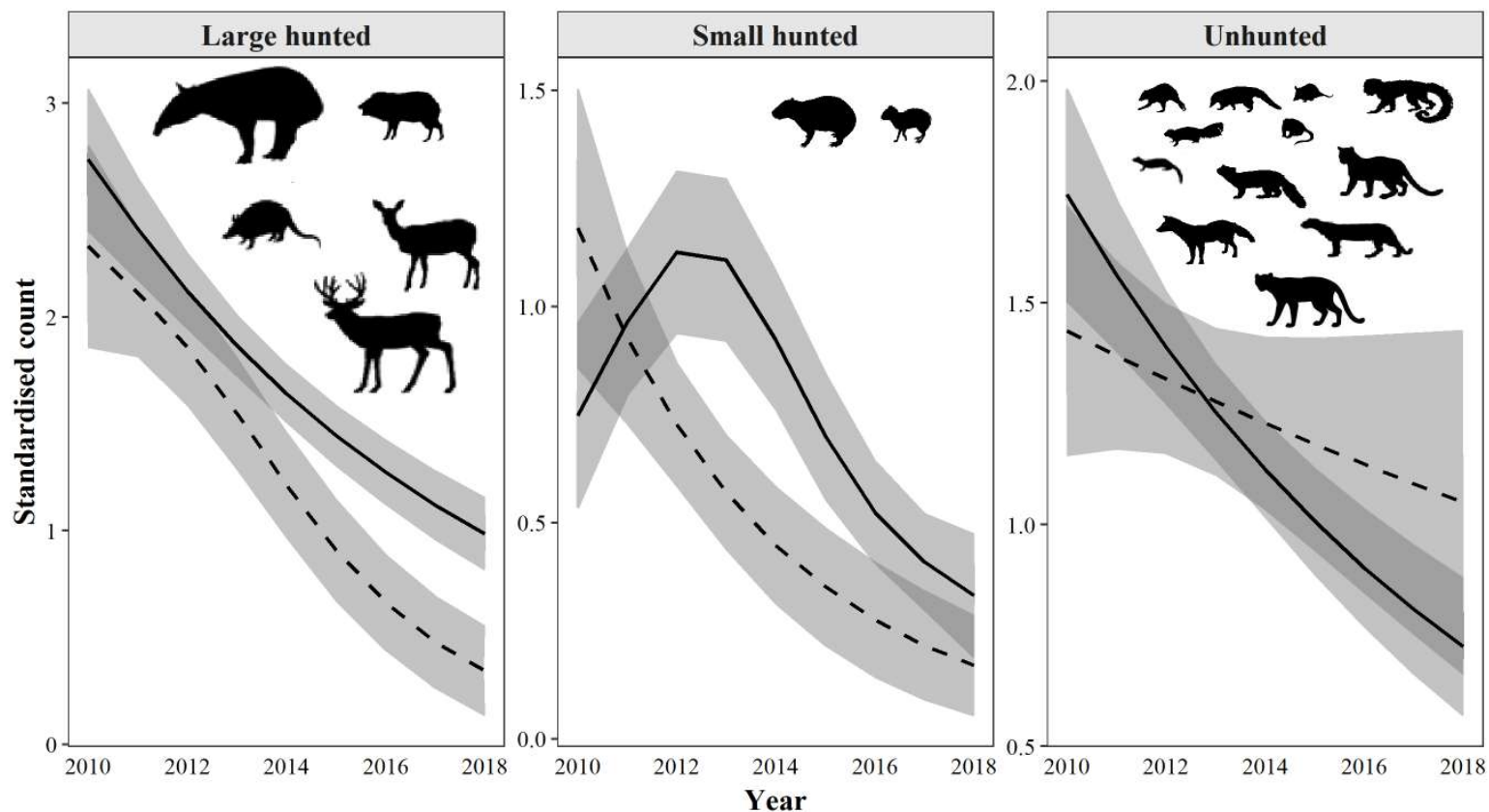

Fig. 2 GAMM-derived trends in standardized counts (detection rates per km walked) $\pm 95 \%$ confidence intervals (shaded) from 2010 to 2018 within the core zone (solid line) and the buffer zone (dashed line) of Cusuco National Park for each mammal group including a) large hunted, b) small hunted and c) unhunted species aggregated. 
a)
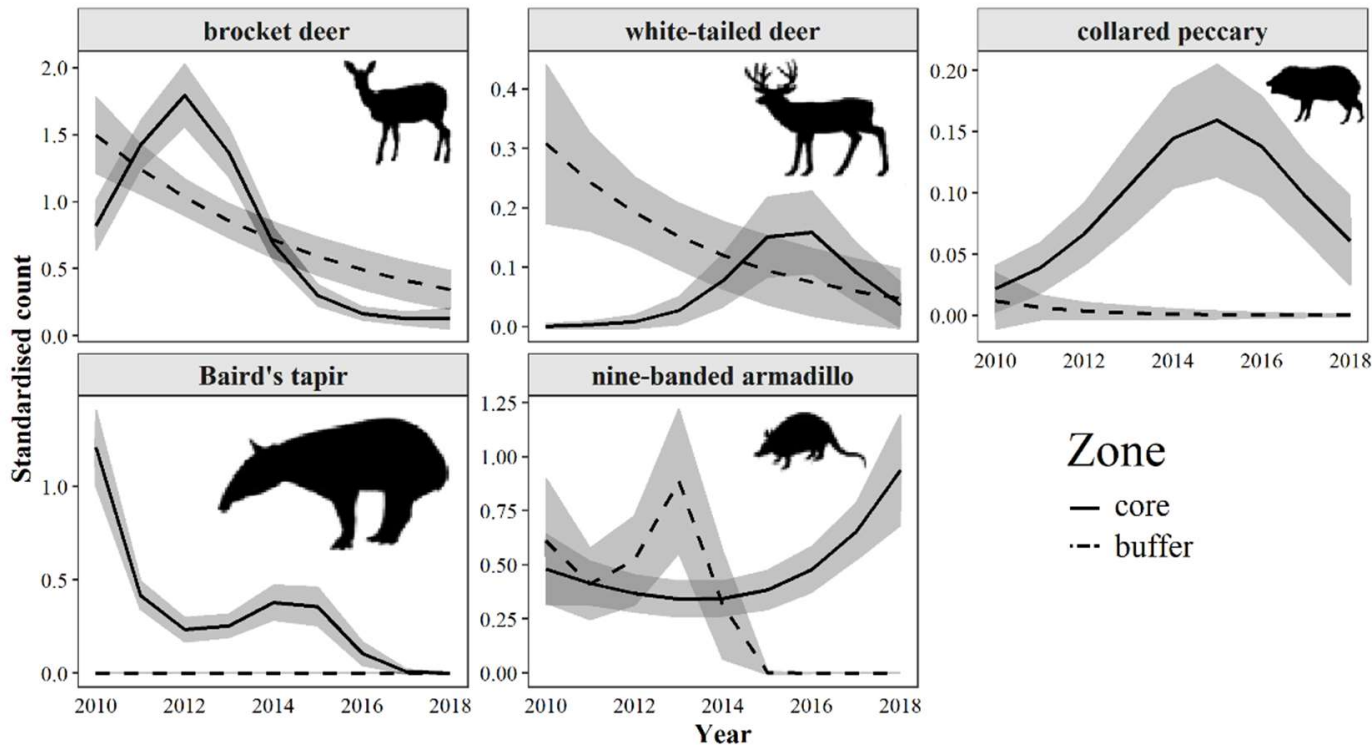

b)

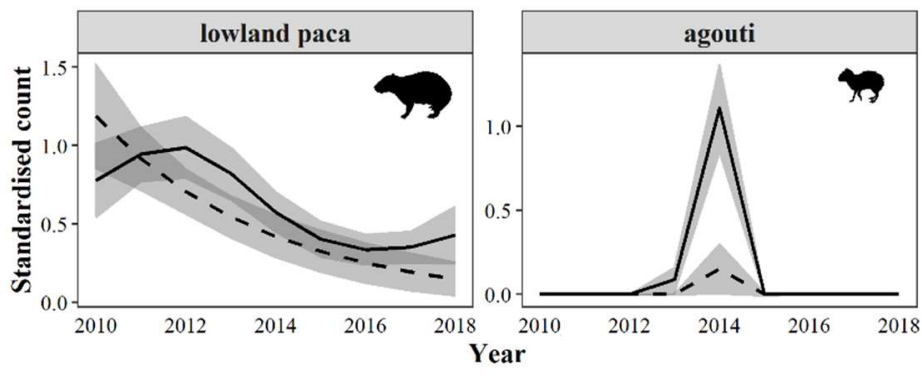

c)
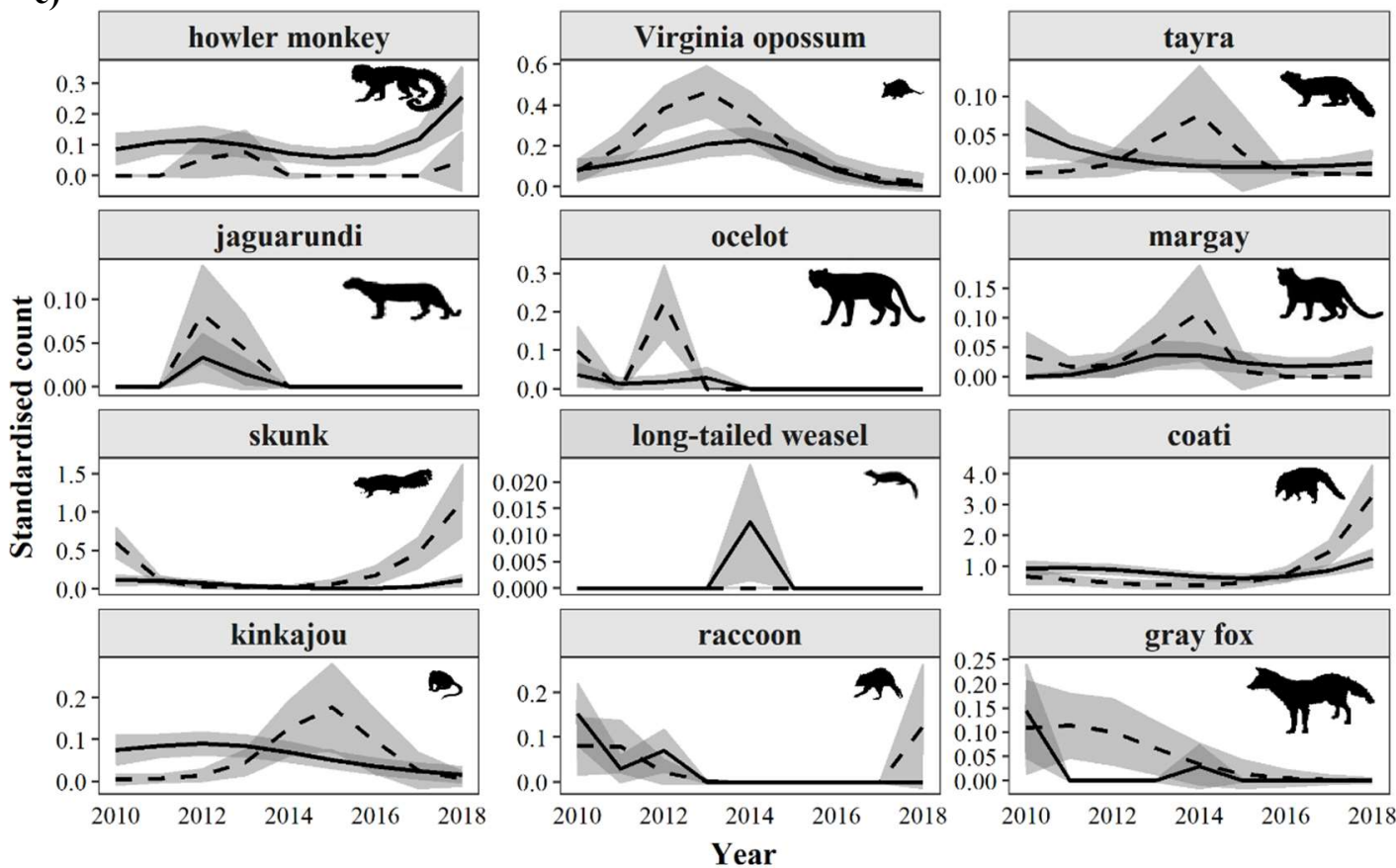

Fig. 3 Species-specific GAMM-derived trends in standardized counts (detection rates per km walked) $\pm 95 \%$ confidence intervals (shaded) from 2010 to 2018 within the core zone (solid line) and the buffer zone (dashed line) of Cusuco National Park including a) large hunted, b) small hunted and c) unhunted species. 
Table 1 Species-specific tracks and signs detected from 2010 to 2018 in Cusuco National Park, Honduras.

\begin{tabular}{|c|c|c|c|c|c|c|c|c|c|c|}
\hline \multirow{2}{*}{$\begin{array}{l}\text { Grouping } \\
\text { Common name (Scientific name) }\end{array}$} & \multicolumn{9}{|c|}{ Year } & \multirow[b]{2}{*}{ Total } \\
\hline & 10 & 11 & 12 & 13 & 14 & 15 & 16 & 17 & 18 & \\
\hline \multicolumn{11}{|l|}{ a) Large hunted } \\
\hline Baird's tapir (Tapirus bairdii) & 97 & 17 & 20 & 13 & 25 & 16 & 1 & 1 & 0 & 397 \\
\hline brocket deer (Mazama temama) & 79 & 78 & 143 & 67 & 46 & 0 & 9 & 3 & 18 & 472 \\
\hline collared peccary (Pecari tajacu) & 0 & 7 & 5 & 0 & 14 & 7 & 4 & 4 & 2 & 43 \\
\hline nine-banded armadillo (Dasypus novemcinctus) & 37 & 13 & 32 & 25 & 12 & 10 & 18 & 30 & 64 & 269 \\
\hline white-tailed deer (Odocoileus virginianus) & 18 & 3 & 8 & 4 & 1 & 19 & 0 & 5 & 3 & 72 \\
\hline Sub-total & 231 & 118 & 208 & 109 & 98 & 52 & 32 & 43 & 87 & 1253 \\
\hline \multicolumn{11}{|l|}{ b) Small hunted } \\
\hline lowland paca (Cuniculus paca) & 66 & 55 & 66 & 49 & 23 & 10 & 5 & 18 & 31 & 340 \\
\hline agouti (Dasyprocta punctata) & 0 & 0 & 0 & 1 & 34 & 0 & 0 & 0 & 0 & 38 \\
\hline Sub-total & 66 & 55 & 66 & 50 & 57 & 10 & 5 & 18 & 31 & 378 \\
\hline \multicolumn{11}{|l|}{ c) Unhunted } \\
\hline howler monkey (Alouatta palliata) & 7 & 6 & 9 & 3 & 3 & 2 & 0 & 3 & 19 & 88 \\
\hline Virginia opossum (Didelphis virginiana) & 12 & 3 & 15 & 14 & 25 & 0 & 2 & 0 & 3 & 86 \\
\hline tayra (Eira barbara) & 6 & 1 & 1 & 2 & 2 & 0 & 0 & 0 & 2 & 16 \\
\hline jaguarundi (Herpailurus yagouaroundi) & 0 & 0 & 5 & 2 & 0 & 0 & 0 & 0 & 0 & 8 \\
\hline ocelot (Leopardus pardalis) & 5 & 1 & 10 & 3 & 0 & 0 & 0 & 0 & 0 & 20 \\
\hline margay (Leopardus wiedii) & 0 & 0 & 0 & 0 & 5 & 0 & 1 & 0 & 2 & 8 \\
\hline skunk (Mephitis sp.) & 17 & 3 & 6 & 4 & 0 & 0 & 2 & 1 & 22 & 57 \\
\hline long-tailed weasel (Mustela frenata) & 0 & 0 & 0 & 0 & 1 & 0 & 0 & 0 & 0 & 1 \\
\hline white-nosed coati (Nasua narica) & 77 & 37 & 94 & 26 & 46 & 9 & 16 & 32 & 88 & 493 \\
\hline kinkajou (Potos flavus) & 4 & 5 & 8 & 3 & 7 & 1 & 4 & 0 & - & 32 \\
\hline raccoon (Procyon lotor) & 6 & 3 & 4 & 0 & 0 & 0 & 0 & 0 & 1 & 16 \\
\hline gray fox (Urocyon cinereoargenteus) & 9 & 0 & 0 & 0 & 3 & 0 & 0 & 0 & 0 & 12 \\
\hline Sub-total & 143 & 59 & 152 & 62 & 92 & 12 & 26 & 37 & 137 & 847 \\
\hline Total & 440 & 232 & 426 & 221 & 247 & 74 & 63 & 98 & 255 & 2478 \\
\hline
\end{tabular}


Table 2 Species-specific temporal trends for a) large hunted, b) small hunted and c) unhunted mammal species in Cusuco National Park showing the effect of Year fitted as i) a continuous variable to obtain a GLM trend (2010-2018) with \% change since baseline and ii) a fixed factor to capture GAMM inter-annual variation.

\begin{tabular}{|c|c|c|c|c|c|c|c|}
\hline \multirow{2}{*}{$\begin{array}{l}\text { Grouping } \\
\text { Species }\end{array}$} & \multirow[t]{2}{*}{ Zone } & \multicolumn{3}{|c|}{ Linear regression } & \multirow[b]{2}{*}{$\%$ change } & \multicolumn{2}{|c|}{ GAMM } \\
\hline & & $t$ & $\beta \pm$ s.e. & $p$ & & $F$ & $p$ \\
\hline \multicolumn{8}{|l|}{ a) Large hunted } \\
\hline \multirow[t]{2}{*}{ Baird’s tapir } & Core & -4.61 & $-0.37 \pm 0.08$ & $<0.001$ & -100 & 9.46 & $<0.001$ \\
\hline & Buffer & 0.00 & $0.00 \pm 0.00$ & 1.000 & 0 & 0.00 & 1.000 \\
\hline \multirow[t]{2}{*}{ Brocket deer } & Core & -6.33 & $-0.26 \pm 0.04$ & $<0.001$ & -85 & 16.70 & $<0.001$ \\
\hline & Buffer & -2.28 & $-0.19 \pm 0.08$ & 0.026 & -77 & 7.68 & 0.006 \\
\hline \multirow{2}{*}{ White-tailed deer } & Core & 1.47 & $0.25 \pm 0.17$ & 0.143 & 3454 & 1.42 & 0.199 \\
\hline & Buffer & -1.20 & $-0.24 \pm 0.20$ & 0.234 & -85 & 2.01 & 0.158 \\
\hline \multirow{2}{*}{ Collared peccary } & Core & 1.03 & $0.10 \pm 0.10$ & 0.306 & 179 & 2.07 & 0.099 \\
\hline & Buffer & -0.93 & $-0.59 \pm 0.64$ & 0.355 & -99 & 0.25 & 0.620 \\
\hline \multirow[t]{2}{*}{ Nine-banded armadillo } & Core & 1.78 & $0.09 \pm 0.05$ & 0.077 & 96 & 3.14 & 0.042 \\
\hline & Buffer & -1.54 & $-0.23 \pm 0.15$ & 0.127 & -100 & 0.90 & 0.439 \\
\hline \multirow[t]{2}{*}{ Sub-total } & Core & -4.38 & $-0.13 \pm 0.03$ & $<0.001$ & -64 & 17.50 & $<0.001$ \\
\hline & Buffer & -2.86 & $-0.20 \pm 0.07$ & 0.006 & -85 & 5.14 & 0.008 \\
\hline \multicolumn{8}{|l|}{ b) Small hunted } \\
\hline \multirow[t]{2}{*}{ Lowland paca } & Core & -3.43 & $-0.13 \pm 0.04$ & $<0.001$ & -45 & 2.93 & 0.034 \\
\hline & Buffer & -1.62 & $-0.26 \pm 0.16$ & 0.109 & -87 & 5.53 & 0.020 \\
\hline \multirow[t]{2}{*}{ Agouti } & Core & 0.06 & $0.01 \pm 0.11$ & 0.956 & 0 & 4.52 & 0.012 \\
\hline & Buffer & 0.69 & $0.18 \pm 0.27$ & 0.493 & 0 & 0.05 & 0.955 \\
\hline \multirow[t]{2}{*}{ Sub-total } & Core & -3.02 & $-0.11 \pm 0.04$ & 0.003 & -56 & 3.17 & 0.023 \\
\hline & Buffer & -1.59 & $-0.24 \pm 0.15$ & 0.116 & -86 & 5.30 & 0.022 \\
\hline \multicolumn{8}{|l|}{ c) Unhunted } \\
\hline \multirow[t]{2}{*}{ Howler monkey } & Core & 1.08 & $0.09 \pm 0.08$ & 0.281 & 200 & 2.00 & 0.122 \\
\hline & Buffer & 0.27 & $0.05 \pm 0.19$ & 0.789 & NA & 0.13 & 0.942 \\
\hline \multirow{2}{*}{ Virginia opossum } & Core & -1.17 & $-0.11 \pm 0.09$ & 0.242 & -94 & 2.35 & 0.073 \\
\hline & Buffer & -0.34 & $-0.04 \pm 0.12$ & 0.733 & -71 & 2.42 & 0.053 \\
\hline \multirow[t]{2}{*}{ Tayra } & Core & -1.37 & $-0.25 \pm 0.18$ & 0.173 & -76 & 1.44 & 0.226 \\
\hline & Buffer & 0.26 & $0.08 \pm 0.30$ & 0.796 & -100 & 0.61 & 0.567 \\
\hline Jaguarondi & Core & -0.87 & $-0.27 \pm 0.31$ & 0.387 & -100 & 0.20 & 0.861 \\
\hline & Buffer & -0.45 & $-0.11 \pm 0.25$ & 0.652 & -100 & 0.21 & 0.853 \\
\hline Ocelot & Core & -2.65 & $-0.50 \pm 0.19$ & $<0.001$ & -100 & 0.28 & 0.830 \\
\hline & Buffer & -1.17 & $-0.40 \pm 0.34$ & 0.245 & -100 & 0.46 & 0.709 \\
\hline Margay & Core & 0.76 & $0.12 \pm 0.16$ & 0.446 & NA & 0.51 & 0.679 \\
\hline & Buffer & -0.23 & $-0.06 \pm 0.24$ & 0.815 & -100 & 0.76 & 0.539 \\
\hline Skunk & Core & -1.12 & $-0.12 \pm 0.12$ & 0.264 & -1 & 1.75 & 0.158 \\
\hline & Buffer & 0.78 & $0.11 \pm 0.14$ & 0.440 & 90 & 6.62 & $<0.001$ \\
\hline Long-tailed weasel & Core & 0.05 & $0.02 \pm 0.38$ & 0.964 & 0 & 0.01 & 0.987 \\
\hline & Buffer & 0.00 & $0.00 \pm 0.00$ & 1.000 & 0 & 0.00 & 1.000 \\
\hline White-nosed coati & Core & 0.13 & $0.01 \pm 0.04$ & 0.898 & 34 & 2.23 & 0.146 \\
\hline & Buffer & 3.28 & $0.22 \pm 0.07$ & 0.001 & 395 & 9.40 & $<0.001$ \\
\hline Kinkajou & Core & -1.26 & $-0.13 \pm 0.11$ & 0.211 & -67 & 1.20 & 0.309 \\
\hline & Buffer & 1.81 & $0.33 \pm 0.18$ & 0.075 & 401 & 1.84 & 0.154 \\
\hline Raccoon & Core & -3.76 & $-0.90 \pm 0.24$ & $<0.001$ & -100 & 0.87 & 0.435 \\
\hline & Buffer & -0.72 & $-0.18 \pm 0.25$ & 0.470 & 56 & 0.47 & 0.692 \\
\hline Gray fox & Core & -2.34 & $-0.93 \pm 0.40$ & 0.020 & -100 & 0.36 & 0.781 \\
\hline & Buffer & -0.94 & $-0.34 \pm 0.36$ & 0.348 & -99 & 0.37 & 0.723 \\
\hline Sub-total & Core & -2.93 & $-0.11 \pm 0.04$ & 0.004 & -59 & 8.37 & 0.004 \\
\hline & Buffer & -0.61 & $-0.04 \pm 0.06$ & 0.541 & -27 & 0.40 & 0.530 \\
\hline Grand total (all spe & $\begin{array}{l}\text { Core } \\
\text { Buffer }\end{array}$ & $\begin{array}{l}-4.71 \\
-2.28\end{array}$ & $\begin{array}{l}-\mathbf{- 0 . 1 2} \pm \mathbf{0 . 0 3} \\
-\mathbf{0 . 1 5} \pm \mathbf{0 . 0 7}\end{array}$ & $\begin{array}{r}<0.001 \\
0.026\end{array}$ & $\begin{array}{l}-62 \\
-70\end{array}$ & $\begin{array}{l}17.8 \\
7.74\end{array}$ & $\begin{array}{r}<0.001 \\
0.006\end{array}$ \\
\hline
\end{tabular}




\section{$\underline{\text { Supplementary Materials }}$}

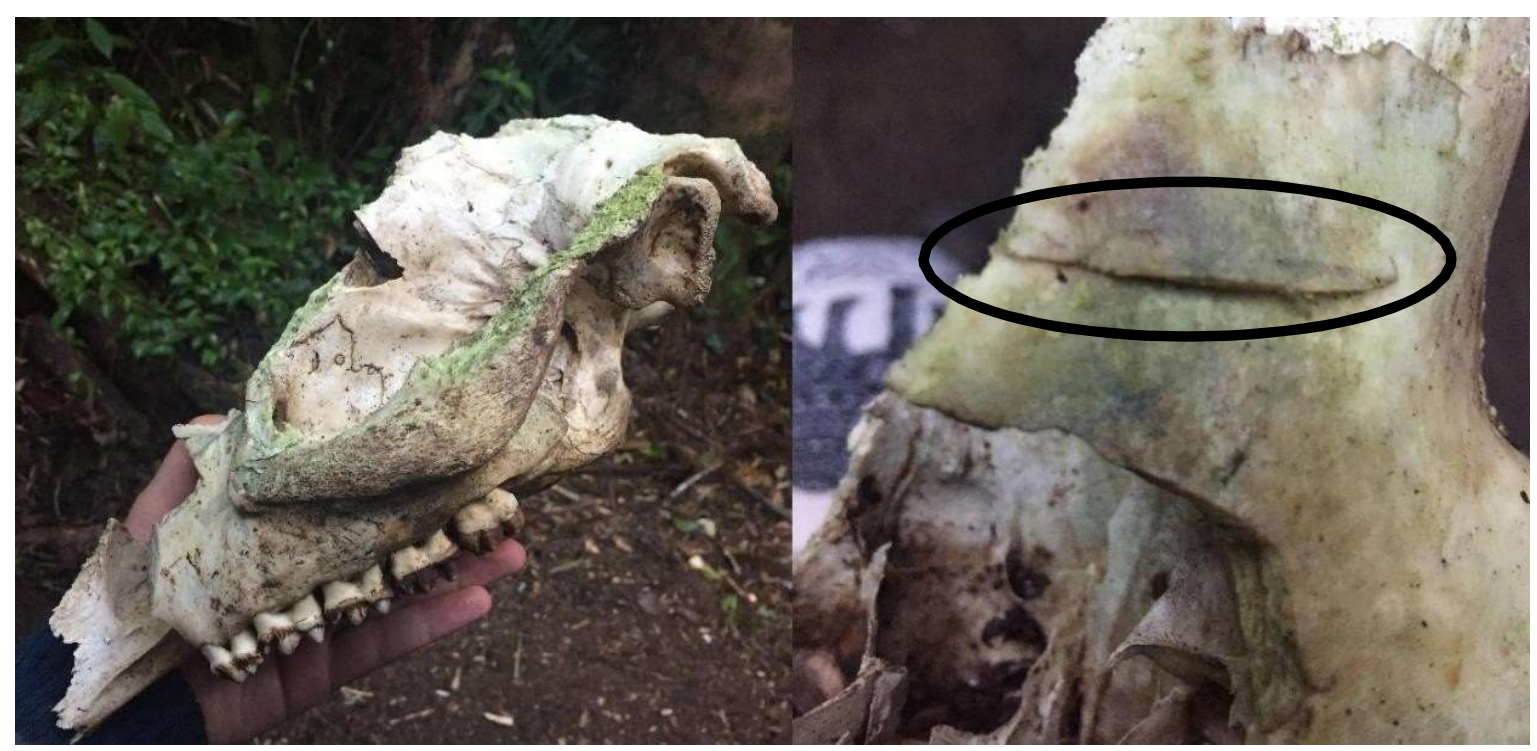

Fig. S1 Skull of a Baird's tapir (T. bairdii) found along the Rio Cusuco close to the Cantiles research stations (camp) during 2017 (left panel) with evidence of machete marks (right panel) suggesting it was butchered for bushmeat. The species is currently IUCN Red Listed as Endangered (category A2abcd +3 bcde) with a declining population trend. 


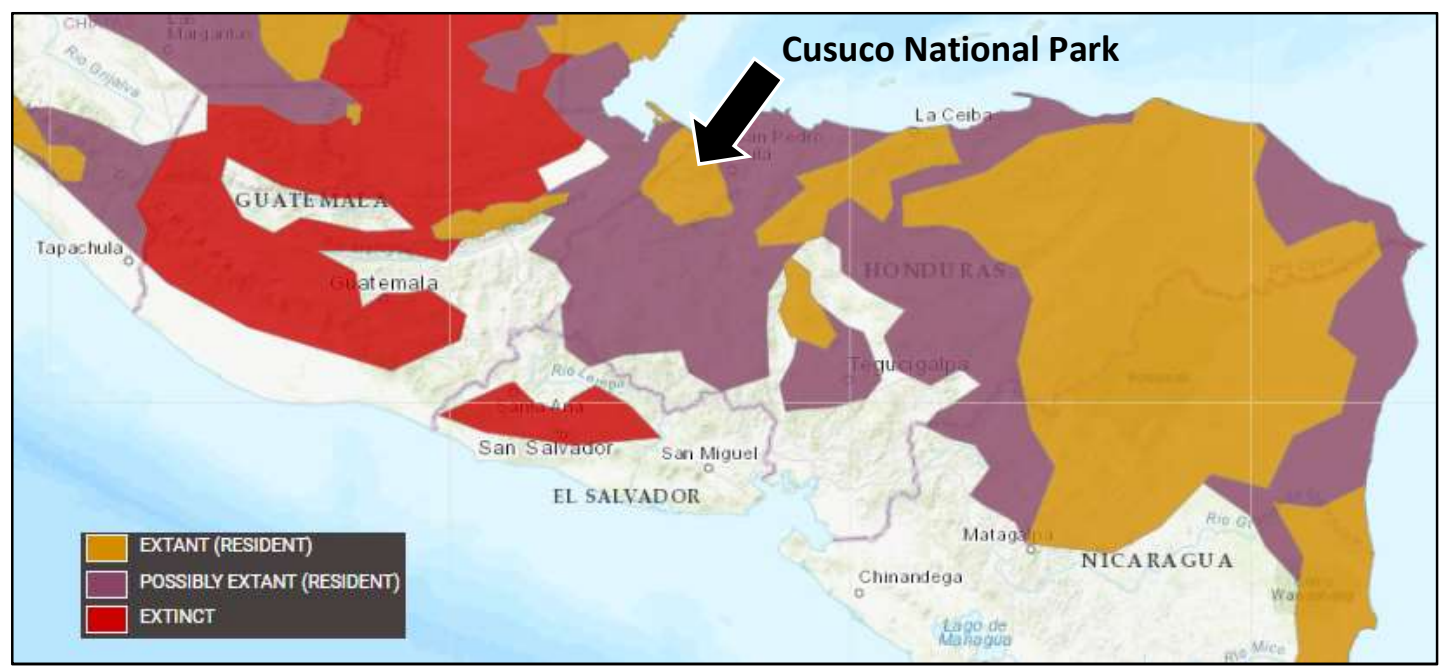

Fig. S2 IUCN Red List range map for the endangered and declining Baird's tapir (Tapirus bairdii) in Central America (reproduced from Garcìa et al. 2016) showing local extirpation in Guatemala and El Salvador with an extant resident population associated with Cusuco National Park now shown by this study to be at imminent risk of local extinction. 